\title{
The Effect of Profitability, Company Size, Company Growth on Firm Value Through Capital Structure in Food and Beverage Companies on the Indonesia Stock Exchange 2014-2018 Period
}

\author{
Wardi Antoro', Anwar Sanusi ${ }^{2}$, and Prihat Asih ${ }^{3}$ \\ ${ }^{1}$ Student in Magister Management Program, University of Merdeka Malang \\ ${ }^{2,3}$ Lecturer in Faculty of Economics and Business, University of Merdeka Malang \\ Indonesia
}

\begin{abstract}
This research was conducted to examine the effect of profitability, company size and company growth on firm value through the capital structure of food and beverage companies listed on the IDX for the 2014-2018 period. The analysis was carried out using secondary data, namely financial reports on the Indonesian Stock Exchange. The technique used in sampling is purposive sampling. The number of samples obtained were 11 food and beverage companies. The analysis technique uses path analysis. The results of the analysis show that profitability has a positive (significant) effect on capital structure, firm size and firm growth has no effect on capital structure, profitability has a positive (significant) effect on firm value. Firm size and company growth have no effect on firm value, capital structure has a negative (significant) effect on firm value. This research shows that investors and traders only pay attention to the profitability of the company to assess the company, have not considered the size of the company and the growth of the company and the capital structure.
\end{abstract}

Keywords: Profitability, Company Size, Company Growth, Capital Structure, Firm Value.

\section{INTRODUCTION}

In this era of globalization, the development of the business world, both in the service sector and in production, is developing very rapidly, causing intense competition in the business world. Thus requiring companies to compete to achieve company goals. One of the company's goals is to maximize shareholder wealth, which means increasing the value of the company (Harmono, 2018; 1) [1].

The importance of firm value makes investors and creditors more selective in investing, for investors, the value of the company will give a positive signal to be able to invest in a company, while for creditors the value of this company reflects the ability of a company to pay its debts and provides a sense of security for creditors in provide loans to companies. To get the attention of these investors, the company must be able to maximize its performance and pay attention to the factors that influence it, so that the firm value is maximized.

The problem of capital structure is a very important problem for every company, because good and bad capital structure will directly affect its financial position. Therefore, one of the tough tasks of financial managers is to determine the optimum capital structure to maximize firm value. In accordance with the research of Sofia and Akhmadi (2018) [2]; Khoiril, et al (2018) [3]; Hermuningsih (2012) [4] shows that capital structure has a positive effect on firm value. Meanwhile Dewi and Sudiarta (2017) [5] state that capital structure has a negative and insignificant effect on firm value.

One of the factors that influence firm value is profitability. Companies that have good financial performance or profitability will have an impact on their stock prices, so that if the stock price rises, investors will enjoy the benefits (Lubis. Et al., 2017). [6] According to research results (Dhani and Utama, 2017) [7]; Chen and Chen (Sofia and Akhmadi, 2018) [2]; Dewi and Sudiartha (2017) [5]; Rahayu and Sari (2018) [8] show that profitability has a positive effect on firm value. Meanwhile, Azmi, et al (2018) [9] stated that profitability has a positive and insignificant effect on firm value.

Another factor that can affect firm value is company size. If a company has large total assets, management will find it easier to obtain funding sources and use them. This is because creditors will have more confidence in providing loans to convincing companies in the hope of repaying the loan along with the required interest. Research conducted by Kosformasi (2017) 
[10]; Habsari (2018) [11] found that the relationship between firm size and firm value is positive and significant. Meanwhile, Indriyani (2017) [12] states that company size has a negative effect on firm value.

In addition, factors that can affect firm value are company growth. The greater the assets owned and followed by an increase in operations, it is hoped that it will be able to increase external confidence in the company. In accordance with Gustian's research (2017) [13]; Khoiril, et al (2018) [3] company growth has a significant positive effect on firm value. Meanwhile, Santoso (2018) [14] states that company growth has no effect on firm value

The choice of food and beverage companies in this study is because the food and beverage sub-sector companies provide a large contribution among other sub-sectors to a country's economy. According to the Forbil Institute [15], data on Gross Domestic Product (GDP) for several industries during the 2014 - 2018 period, the value of the food and beverage industry shows an increasing trend from 2014 to 2018. In 2014 the trend of the food and beverage industry reached 117 trillion rupiah and continues to increase to reach 165 trillion rupiah in 2018.

\section{THEORITICAL REVIEW}

a. The value of the company

Firm value is the company's performance as reflected by the stock price which is formed by supply and demand in the capital market which reflects the public's assessment. (Harmono, 2018; 233). [1] According to Rahayu and Sari (2018) [8], firm value is a certain condition that has been achieved by a company which is reflected in the market price of the company's stock. So firm value is a public assessment of the company's success rate which is usually associated with the company's stock price.

\section{b. Capital Structure}

The capital structure is an illustration of the form of the company's financial proportion that comes from long-term debt and its own capital which is the source of a company's financing, (Fahmi 2018; 184), [16]. Capital structure theory is a theory that explains whether long-term spending policies can affect firm value, the company's cost of capital, and the company's stock price. (Sudana, 2011: 143) [17] Directly, capital structure decisions will affect the condition and value of the company and determine the company's ability to survive or develop. The trade-off theory explains that if the capital structure target point is not optimal, then each additional debt will increase the firm's value. Conversely, if the capital structure is above the optimum target point, then any additional debt will decrease the firm's value.

\section{c. Profitability}

Profitability is the profit a company generates from the company's operations based on its performance measurement. Profitability is the company's ability to earn profits in relation to sales, total assets and own capital (Sartono, 2015: 122). [18] High profitability indicates that the prospects for the company are good. In accordance with one signal theory which states that companies with high profitability will provide positive signals for investors, which in turn, investors will react to buying shares. Responses and positive reactions from these investors will increase stock prices and will further increase the company's value.

\section{d. Company Size}

Company size is the size of the company seen from the value of equity, sales value, asset value. (Riyanto, 2010; 313) [19] The size of the company will affect the company's debt policy, the bigger the company, the greater the funds needed by the company to make investments. (Sofia and Akhmadi, 2018) [2]

A large company size can show that the company is experiencing development and is a good signal for investors. Investors will respond positively, which causes the stock price to rise and further increase the value of the company

\section{e. Company Growth}

Company growth is the company's ability to increase its size. (Gustian, 2017)

[13] For investors, company growth shows positive signals and good development, the growth of a company will have a beneficial impact. The better the company's growth can increase the company's value. 


\section{f. Conceptual Framework}

Figure 1. Conceptual framework

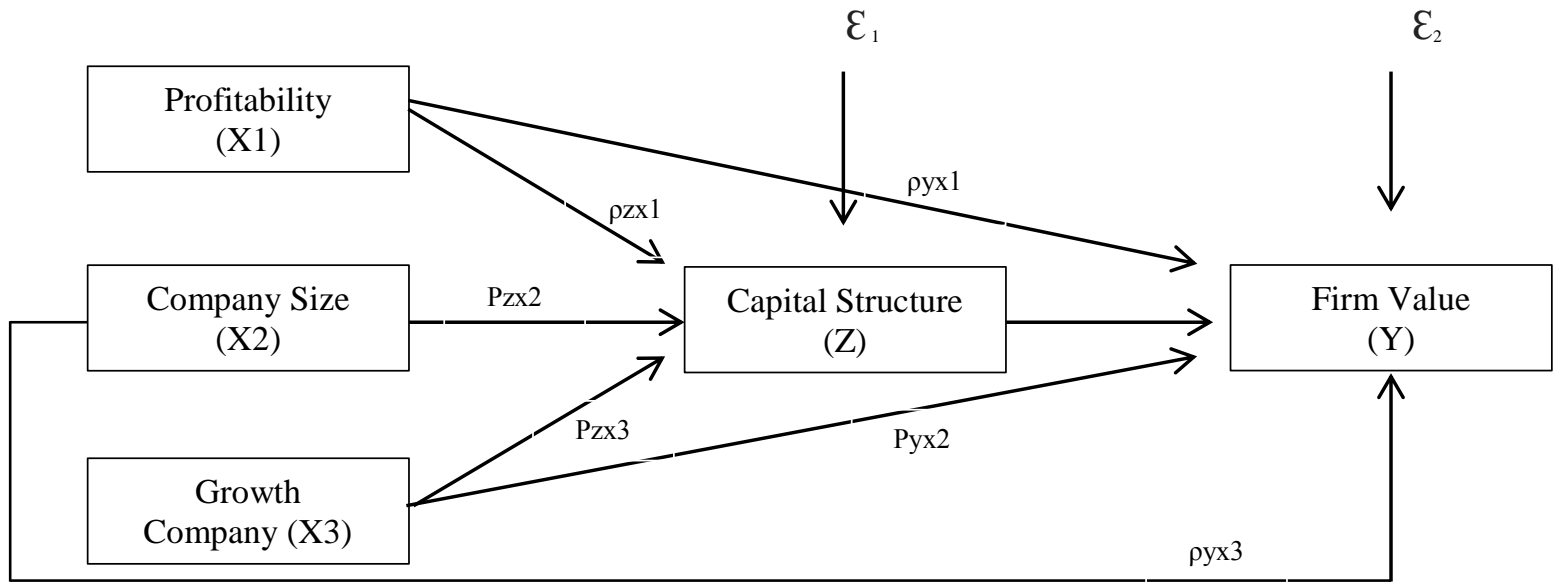

Description: X1, X2, X3 $\rightarrow$ independent variable

$\mathrm{Z} \rightarrow$ intervening variables

Y $\rightarrow$ dependent variable

g. Hypothesis

The hypotheses in this study are:

1. Profitability, company size and company growth have a positive effect on capital structure.

2. Profitability, company size and company growth have a positive effect on firm value.

3. Capital structure affects firm value.

4. Profitability, company size, and company growth have a positive effect on firm value through capital structure

\section{RESEARCH METHODS}

a. Population and Sampling Techniques

The population in this study amounted to 18 food and beverage companies listed on the IDX for the 2014-2018 period. By using purposive sampling, which is a sampling method based on certain considerations, especially the considerations given by a group of experts or experts. (Sanusi, 2017; 95). [20] With this purposive sampling, 11 food and beverage companies listed on the IDX for the 2014-1018 period were sampled.

Table 1. Sample List of food and beverage companies listed on the IDX

\begin{tabular}{|c|l|}
\hline No. & \multicolumn{1}{|c|}{ Company name } \\
\hline 1 & Wilmar Cahaya Indonesia \\
\hline 2 & Delta Djakarta \\
\hline 3 & Indofood CBP Sukses Makmur \\
\hline 4 & Indofood Sukses Makmur \\
\hline 5 & Multi Bintang Indonesia \\
\hline 6 & Mayora Indah \\
\hline 7 & Nippon Indosari Corporindo \\
\hline 8 & Sekar Bumi \\
\hline 9 & Sekar Laut \\
\hline 10 & Siantar Top \\
\hline 11 & Ultrajaya Milk Industry and Trading Company \\
\hline
\end{tabular}

Source: Indonesia Stock Exchange, 2019

b. Research variable

There are 2 variables in this study, namely:

1) Independent Variable 
There are 3 independent variables in this study, namely:

(a) Profitability (X1)

Profitability can be measured by the formula:

Return on Equityt $=\frac{\text { Earning after tax }}{\text { Total Equity }} \times 100 \%$

(b) Company Size (X2)

Company size can be measured by the formula:

Size $=$ Natural logarithm (Ln) of Total Asset

(c) Company Growth

Company growth can be measured by the formula:

Total Asset t - Total Assett-1

Firm Growth $=$

2) Dependent Variable

Total Asset ${ }_{\mathrm{t}-1}$

There are 2 dependent variables in this study, namely:

(a) Capital Structure (Z)

Capital structure can be measured by the formula:

Debt to Equity $=\quad \frac{\text { Total Debt }}{\text { Total Capital }} \times 100 \%$

(b) Firm Value (Y)

Firm value can be measured by the formula:

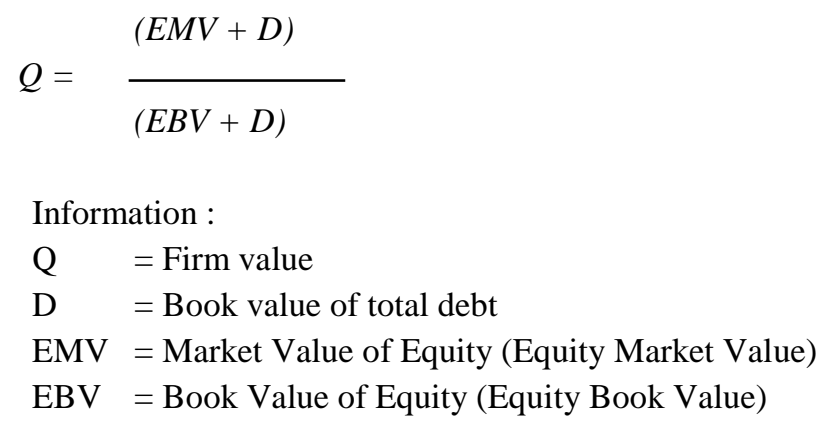

c. Technical Analysis

In this study, the technique used is Path Analysis to determine the direct or indirect effect of various variables using SPSS softwear. Hypothesis testing uses the $t$ test (partial) if the probability is $\geq 0.05$, the hypothesis is rejected, meaning that there is no significant effect of the independent variable on the dependent variable. And if the probability $<0.05$, then the hypothesis is accepted, it means that there is a significant effect of the independent variable on the dependent variable. In this research, there are 2 (two) structural equations, namely:

$$
\begin{aligned}
& Z=\rho_{\mathrm{zx} 1} \mathrm{x} 1+\rho_{\mathrm{zx} 2} \mathrm{x} 2+\rho_{\mathrm{zx} 3} \mathrm{x} 3+\mathcal{E} 1 \\
& Y=\rho \mathrm{yx} 1 \mathrm{X} 1+\rho_{\mathrm{yx} 2} \mathrm{X} 2+\rho_{\mathrm{yx} 3} \mathrm{X} 3+\rho \mathrm{yz} Z+\varepsilon 2
\end{aligned}
$$

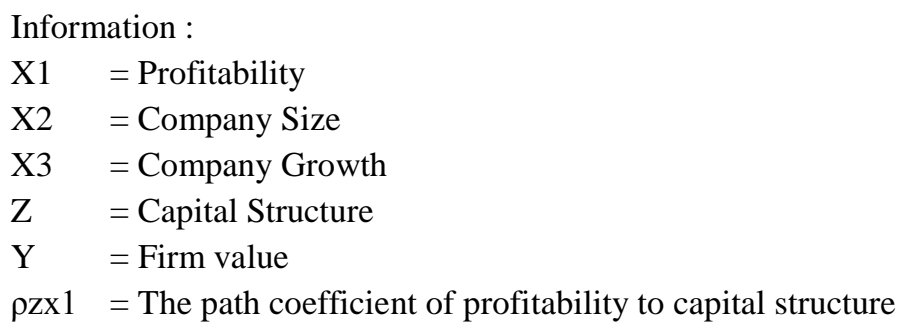


$\mathrm{zx} 2=$ The path coefficient of firm size on capital structure

$\mathrm{zx} 3=$ Company growth path coefficient against capital structure

pyz $\quad=$ The path coefficient of capital structure on firm value

pyx1 = The path coefficient of profitability to firm value

pyx2 = The path coefficient of firm size on firm value

$\rho y x 3=$ The path coefficient of company growth on firm value

$\varepsilon \quad=$ The influence of other factors

\section{RESEARCH RESULTS AND DISCUSSION}

\subsection{Path Analysis}

The first equation is to determine the relationship between variables, namely profitability, company size, and company growth on capital structure which can be shown in the following tables:

Table 2. Profitability, firm size and company growth have a positive effect on firm value through capital structure

\begin{tabular}{|c|c|c|c|c|c|}
\hline Regression & $\begin{array}{c}\text { Direct } \\
\text { Influence }\end{array}$ & T count & P Value & Indirect Effect & Total Effect \\
\hline $\begin{array}{l}\text { Profitability (X1) } \rightarrow \text { Capital } \\
\text { Structure }(\mathrm{Z})\end{array}$ & 0.535 & 4.539 & 0.000 & & \\
\hline $\begin{array}{l}\text { Size }(X 2) \rightarrow \text { Capital Structure } \\
(\mathrm{Z})\end{array}$ & -0.007 & -0.062 & 0.951 & & \\
\hline $\begin{array}{l}\text { Firm Growth }(\mathrm{X} 3) \rightarrow \text { Capital } \\
\text { Structure }(\mathrm{Z})\end{array}$ & 0.148 & 1.231 & 0.224 & & \\
\hline $\begin{array}{l}\text { Profitability }(\mathrm{X} 1) \rightarrow \text { Firm } \\
\text { Value }(\mathrm{Y})\end{array}$ & 1.011 & 17.705 & 0.000 & & \\
\hline Size $(\mathrm{X} 2) \rightarrow$ Firm Value $(\mathrm{Y})$ & 0.023 & 0.458 & 0.649 & & \\
\hline $\begin{array}{l}\text { Firm Growth }(\mathrm{X} 3) \rightarrow \text { Firm } \\
\text { Value }(\mathrm{Y})\end{array}$ & 0.023 & 0.454 & 0.652 & & \\
\hline $\begin{array}{l}\text { Capital Structure }(\mathrm{Z}) \rightarrow \text { Firm } \\
\text { Value }(\mathrm{Y})\end{array}$ & -0.140 & -2.443 & 0.018 & & \\
\hline $\begin{array}{l}\text { Profitability } \rightarrow \text { Capital } \\
\text { Structure } \rightarrow \text { Firm Value }\end{array}$ & 1.011 & - & - & $(0.535) \times(-0.140)=-0.075$ & $(1.011)+(-0.075)=0.936$ \\
\hline $\begin{array}{l}\text { Firm Size } \rightarrow \text { Capital Structure } \\
\rightarrow \text { Firm Value }\end{array}$ & 0.023 & - & - & $(-0.007) \times(-0.140)=0.000$ & $(0.023)+(0.000)=0.023$ \\
\hline $\begin{array}{l}\text { Firm Growth } \rightarrow \text { Capital } \\
\text { Structure } \rightarrow \text { Firm Value }\end{array}$ & 0.023 & - & - & $(0.148) \times(-0.140)=-0.021$ & $(0.023)+(-0.021)=0.002$ \\
\hline
\end{tabular}

Source: processed data

So that the structural equation model is as follows:

$\mathrm{Z}=0.535 \mathrm{X} 1-0.007 \mathrm{X} 2+0.148 \mathrm{X} 3$

$\mathrm{Y}=1.011 \mathrm{X} 1+0.023 \mathrm{X} 2+0.023 \mathrm{X} 3-0.140 \mathrm{z}$

Based on table 2, the $\mathrm{t}$ test results show that the coefficient of the effect of profitability on capital structure is 0.535 with a significance level of 0.000 which is smaller than 0.05 . This shows that the profitability variable has a positive and significant effect on the capital structure variable.

The $t$ test results obtained by the coefficient of influence of company size on capital structure of -0.007 with a significance level of 0.951 which is greater than 0.05 . This shows that the firm size variable has no effect on the capital structure variable.

The $t$ test results obtained by the coefficient of the influence of company growth on capital structure of 0.148 with a significance level of 0.224 which is greater than 0.05 . This shows that the company growth variable has a positive and insignificant effect on the capital structure variable.

The $t$ test results obtained by the coefficient of the effect of profitability on firm value of 1.011 with a significance level of 0.000 which is smaller than 0.05 . This shows that the profitability variable has a positive and significant effect on the firm value variable

The $t$ test results obtained by the coefficient of influence of company size on firm value of 0.023 with a significance level of 0.649 which is greater than 0.05 . This shows that the size variable has a positive and insignificant effect on the firm value variable. 
The $t$ test results obtained by the coefficient of the influence of company growth on firm value of 0.023 with a significance level of 0.652 which is greater than 0.05 . This shows that the company growth variable has a positive and insignificant effect on the firm value variable.

The $t$ test results obtained by the coefficient of the effect of capital structure on firm value of -0.140 with a significance level of 0.018 which is smaller than 0.05 . This shows that the capital structure variable has a negative and significant effect on the firm value variable.

The magnitude of the direct effect of profitability on firm value is 1.011 and the magnitude of the indirect effect of profitability on firm value through capital structure is -0.075 and the total effect of profitability on firm value through capital structure is 0.936 . Because the total effect is smaller than the direct effect $(0.936<1.011)$, this shows that the profitability variable has no effect on firm value through the capital structure.

The magnitude of the direct effect of firm size on firm value is 0.023 and the size of the indirect effect of firm size on firm value through capital structure is 0.001 and the total effect of firm size on firm value through capital structure is 0.024 . Because the total effect is greater than the direct effect $(0.024>0.023)$, this shows that the firm size variable affects firm value through the capital structure.

The magnitude of the direct influence of company growth on firm value is 0.023 and the magnitude of the indirect effect of company growth on firm value through capital structure is -0.021 and the total effect of company growth on firm value is 0.002 . Because the total effect is smaller than the direct effect $(0.002<0.023)$, this shows that the firm growth variable has no effect on firm value through the capital structure.

\subsection{Discussion}

\section{a. Profitability, company size and company growth have a positive effect on capital structure.}

The coefficient of the effect of profitability on capital structure is 0.535 with a significance level of 0.000 , which is smaller than 0.05 . This shows that the profitability variable has a positive and significant effect on the capital structure variable. The coefficient of influence of company size on capital structure is -0.007 with a significance level of 0.951 which is greater than 0.05 . This shows that the firm size variable has no effect on the capital structure variable. The coefficient of the influence of company growth on capital structure is 0.148 with a significance level of 0.224 which is greater than 0.05 . This shows that the company growth variable has no effect on the capital structure variable.

This means that the greater the level of profitability obtained by food and beverage companies, the higher the use of the capital structure that comes from debt. High profitability illustrates that the company's performance is good and has long-term prospects. Due to high profitability, the company wants to continue to grow and make new investments to encourage more profit increases in the future, so the company needs more funds. In accordance with the trade-off theory states that as long as the benefits of debt are greater than the costs incurred, additional debt is still allowed.

The results of this study are supported by research by Dewi and Sudiartha (2017) [5]; Wirawan (2017) [21]; Khoiril, et al (2018) [3] stated that profitability has a positive and significant effect on capital structure. In Dewi and Sudiartha's research (2017) [5] which also states that company size has a negative and insignificant effect on debt policy (DER). According to research by Khoiril et al. (2018) [3] also stated that company growth has a positive and insignificant effect on capital structure.

\section{b. Profitability, company size and company growth have a positive effect on firm value.}

The coefficient of the effect of profitability on firm value is 1.011 with a significance level of 0.000 , which is smaller than 0.05. This shows that the profitability variable has a positive and significant effect on the firm value variable. The coefficient of influence of firm size on firm value is 0.023 with a significance level of 0.649 which is greater than 0.05 . This shows that the firm size variable has no effect on the firm value variable. The coefficient of the influence of company growth on firm value is 0.023 with a significance level of 0.652 which is greater than 0.05 . This shows that the company growth variable has no effect on the firm value variable.

This means that the higher the profitability, the higher the firm value, because the high profitability is a reason for investors and traders (traders) to buy shares. In this case investors and traders do not pay attention to the size of the company or the growth of the company, but if the company has high profitability, investors and swords will buy shares of the company with the hope of a large return.

The results of this study are in line with research conducted by Adiyana and Ardiana (2014) [22]; Santoso (2018) [14]; Dewi and Sudiartha (2017) [5]; Indriyani (2017) [12]; Rahayu and Sari (2018) [8]; Dani and Utama (2017) [7] state that profitability has a positive and significant effect on firm value. In Dewi and Sudiartha's research (2017) [5], it shows that company size has a positive and insignificant effect on firm value. According to Dhani and Utama (2017) [7], company growth has a positive and insignificant effect on firm value. 


\section{c. Capital structure affects firm value.}

The coefficient of the effect of capital structure on firm value is -0.140 with a significance level of 0.018 which is smaller than 0.05 . This shows that the capital structure variable has a negative and significant effect on the firm value variable.

This means that any increase in the capital structure will decrease the value of the firm. This shows that companies must be more careful in using debt because if the use of debt exceeds the reasonable limit, too much burden will be paid and will reduce the interest of investors and traders so that the company's value will decrease. In the trade-off theory, it is explained that it is necessary to balance the benefits and sacrifices that arise as a result of using debt, if the sacrifices incurred are greater, then the use of debt is not allowed.

The results of this study support the research of Anggriawan et al. (2017) [23], entitled the effect of capital structure on firm value, partially firm value with the Price earning ratio variable is negatively and significantly affected by capital structure with the Debt equity ratio variable. And what was done by Gustian (2017) [13]; Rahayu and Sari (2018) [8] state that capital structure has a negative and significant effect on firm value.

\section{d. Profitability, company size, and company growth have a positive effect on firm value through capital structure}

Result of influenceThe indirect variables of profitability, firm size and company growth on firm value through capital structure are smaller than the direct effect. This means that the capital structure variable cannot mediate the effect of the variable profitability, company size and company growth on firm value.

Companies with large profitability will attract many investors every year, because investors think that companies with large profits will also produce large returns, this is a positive signal for investors, which will then increase the company's value. This research is in line with research conducted by Azmi, et al (2018) [9]; (Sofia and Akhmadi, 2018) [2] state that the capital structure variable cannot mediate the effect of the variable profitability and firm size on firm value.

\section{CONCLUSIONS AND RECOMMENDATIONS}

Based on the results of the research and discussion described in the previous chapter, it can be concluded that profitability has a positive and significant effect on capital structure. The greater the level of profitability obtained by food and beverage companies, the greater the use of the capital structure that comes from debt to meet the needs of company development. Company size and company growth have no effect on the use of capital structure.

Profitability has a positive and significant effect on capital structure. The greater the company's ability to increase profitability will be a signal for investors and traders (traders) to invest their funds, with investor confidence, the company's value will increase. Capital structure has a negative and significant effect on firm value, in this case management in using debt for company development must be more careful because if it exceeds the fairness limit it will decrease the firm's value. Company size and company growth have no effect on firm value.

Profitability and company size, company growth do not affect firm value through the capital structure because the indirect effect is smaller than the direct effect. This means that the capital structure variable cannot mediate the effect of profitability, firm size and firm growth on firm value.

The results of this study indicate that investors and traders (traders) only pay attention to profitability as a consideration for investing or buying shares for company size and company growth is ignored.

The suggestions that can be given from this research for the company and other interested parties as a basis for consideration are as follows: it is hoped that the company will be able to manage its financial condition, and in investing and expanding it will still pay attention to debt porposiion, so that it can strengthen the company's value. For further researchers, it is necessary to add other variables and indicators that are thought to affect the capital structure and firm value, and to increase the research period so that more accurate information is obtained.

\section{REFERENCES}

1. Harmono, Manajemen Keuangan, Berbasis Balanced Scorecard Pendekatan Teori, Kasus, dan Riset Bisnis, Bumi Aksara Cetakan ketujuh. 2017

2. E. Nurus Sofia dan Akhmadi, Pengaruh Profitabilitas dan Ukuran Perusahaan terhadap Nilai Perusahaan dengan Kebijakan Hutang sebagi Variabel Intervening. Tirtayasa Ekonomika, Vol. 13. No. 1, 2018

3. S. Khoiril, Ari Pranaditya dan Agus Supriyanto, Pengaruh profitabilitas dan Pertumbuhan Perusahaan Terhadap Nilai Perusahaan dengan Struktur Modal sebagai Variabel Intervening. Jurnal Ilmiah Mahasiswa Akuntansi Universitas Pandanaran,,Vol. 5 No. 4, 2018 
4. S. Hermuningsih, Pengaruh Profitabilitas, Size terhadap Nilai Perusahaan dengan Struktur Modal Sebagai Variabel Intervening, Siasat Bisnis, Vol. 16. No. 2, pp 232-242., 2012

5. A.I.Y. Maha Dewi dan Gede Mertha Sudiartha, Pengaruh Profitabilitas, Ukuran Perusahaan, dan Pertumbuhan Aset terhdap Struktur Modal, dan Nilai Perusahaan. E-jurnal Manajemen Unud,,Vol. 6 No. 4, pp: 2222-2252. 2017

6. I.L. Lubis, Bonar M Sinaga dan Hendro Sasongko, Pengaruh profitabilitas, Struktur Modal dan Likuiditas Terhadap Nilai Perusahaan. Jurnal Aplikasi Bisnis dan Manajemen,Vol. 3 No. 3, September 2017

7. I.P. Dani dan A.A Gde Satia Utama, Pengaruh Pertumbuhan Perusahaan, Struktur Modal, dan Profitabiltas Terhadap Nilai Perusahaan. Jurnal Riset Akuntansi dan Bisnis Airlangga, Vol. 2 No. 1. 2017

8. M. Rahayu dan Bida Sari, Faktor-faktor yang Mempengaruhi Nilai Perusahaan. Ikraith-Humaniora. Vol. 2. No. 2. pp. 69-76, 2018

9. N. Azmi, Isnurhadi dan Umar Hamdan,. Pengaruh Profitabilitas, Ukuran Perusahaan terhadap Nilai Perusahaan dengan Struktur Modal sebagai Variabel Intervening pada Perusahaan Manufaktur yang Terdaftar di BEI. Jurnal Ilmiah Manajemen Bisnis dan Terapan, Th. XV No. 2, pp: 95-108., 2018

10. A.D. Kosimpang, Pengaruh profitabilitas, Ukuran Perusahaan Terhadap Nilai Perusahaan dengan Variabel Struktur Modal sebagai Variabel Intervening. Issn 2502.7697, Vol. 3 No. 3, 2017

11. A. Habsari dan Akhmadi, Ukuran Perusahaan, Profitabilitas dan Nilai Perusahaan, Studi Empirik : Perusahaan Sektor Pertambangan yang Terdftardi Bursa Efek Indonesia periode 2011 sampai dengan 2015, Tirtayasa Ekonomika, Vol. 13. No. 2, pp 300-319., 2018

12. E. Indriyani, Pengaruh Ukuran Perusahaan dan Profitabilitas Terhadap NilaiPerusahaan, Jurnal Ilmu Akuntansi, Vol. 10. No. 2, pp 333-348. 2017

13. D. Gustian, Pengaruh Pertumbuhan Perusahaan, Keputusan Investasi, dan Keputusan Pendanaan Terhadap Nilai Perusahaan. Jurnal Akuntansi Universitas Negeri Padang,,Vol. 5 No. 2, 2017

14. A. Santoso, Pengaruh Struktur Aktiva dan Profitabilitas terhadap Struktur Modal Perusahaan Makanan dan Minuman. Trikonomika. Vol. 14. No. 2. pp. 127-135, 2018

15. Forbil E-books, Mengenal Industri Makanan dan Minuman di Era Industri 4.0, https://forbil.org/en/publication/d/21

16. I. Fahmi, Pengantar Manajemen Keuangan "Teori dan Soal Jawab”, Alfabeta, Cetakan keenam, 2018

17. I.M. Sudana, Manajemen Keuangan Perusahaan, Teori dan Praktek. Erlangga. Edisi 2,2011

18. A.Sartono, ManajemenKeuangan:TeoridanAplikasi. EdisiKeempat. Yogyakarta: BPFE, 2015

19. B. Riyanto, Dasar-dasar Pembelanjaan Perusahaan. Yogyakarta BPFE, 2010

20. A.Sanusi, Metode Penelitian Bisnis. Salemba Empat. Cetakan ketujuh, 2017

21. P.A. Wirawan, Pengaruh Struktur Aktiva, Profitabilitas, Ukuran Perusahaan dan Likuiditas terhadap Struktur Modal pada Perusahaan Sektor Barang Konsumsi yang Terdaftar di Bursa Efek Indonesia Periode Tahun 2014-2015. Jurnal Jurusan Pendidikan Ekonomi. Vol. 9. No. 1, 2017

22. I.D.B.G.N.S Adiyana dan Putu Agus Ardiana,. Pengaruh Ukuran Perusahaan, Risiko Bisnis, Pertumbuhan Aset, Profitabilitas dan Tingkat Likuiditas pada Struktur. E-jurnal Akuntansi Universitas Udayana,,Vol. 10 No. 1, pp: 14-30, 2014

23. F. Anggriawan,Topowijono dan Nengah Sudjana, Pengaruh Struktur Modal Terhadap Nilai Perusahaan, Studi pada Perusahaan Sub Sektor Makanan dan Minuman yang Listing di Bursa Efek Indonesia Tahun 2011 - 2015. Jurnal Administrasi Bisnis (JAB),Vol. 50 No. 4, pp: 105-114, 2017. 